\title{
Muslimpreneur Intentions: Analysis of Family Background
}

\author{
Juliana $^{1 *}$, Agus Rahayu², Yuranita Pramudya Wardhani ${ }^{3}$ \\ ${ }^{1}$ Department Islamic Economic and Finance, Universitas Pendidikan Indonesia, Bandung, Indonesia \\ ${ }^{2}$ Department Business Education, Universitas Pendidikan Indonesia, Bandung, Indonesia \\ ${ }^{3}$ Department Islamic Economic and Finance, Universitas Pendidikan Indonesia, Bandung, Indonesia
}

\section{ARTICLE INFO}

\section{Keywords}

Muslimpreneur, Intention, Family

Background.

\section{*Correspondence \\ julian@upi.edu}

\section{Article History}

Received 10 September 2019

Accepted 31 December 2019

Published online 20 January 2020

\begin{abstract}
This research is based on the phenomenon of the problem of high unemployment and low Muslim entrepreneurship in Indonesia. The purpose of this study was to analyze and predict the influence of family background on the intention of the muslimpreneur. The population in this study is students of MA / SMA boarding schools in the city of Bandung. The sampling technique used was a non-probability-accidental sampling technique of 100 people. The method used is causal with a quantitative approach. The data analysis technique used is Patrial Least Square-Structural Equation Modeling (PLS-SEM). The results showed that family background had a positive and significant effect on Muslimpreneur intentions in students of MA / SMA Pesantren in Bandung. The implication in this study is the higher the influence of family background, it will affect the intentions of Islamic entrepreneurship on students.
\end{abstract}

\section{INTRODUCTION}

Minister of Cooperatives, Small and Medium Enterprises (KUKM) Anak Agung Gede Ngurah Puspayoga stated that the ratio of entrepreneurs in Indonesia in 2018 increased to $7 \%$ of the total population of Indonesia. Previously, in 2014, the entrepreneurial ratio in Indonesia was $1.55 \%$, then it increased to $1.65 \%$ in 2016 , rising to $3.1 \%$ at the end of 2017 . The figure was already above international standards (Media Indonesia, 2018). Because according to David McClelland in Juliana (2017), a country can be said to be prosperous if it has a minimum of $2 \%$ of entrepreneurs from the total population of around 4.8 million entrepreneurs from a total population of 240 million people in Indonesia.

But this is still very lacking compared to the number of entrepreneurs in other countries. Enggartiasto Lukita, as Minister of Trade in Indonesia, said that the level of entrepreneurship in Indonesian companies was still relatively low. He explained that Indonesia was only ranked 94 out of 137 countries. In developed countries, the average population of 14 percent of the total working-age is an entrepreneur, while in Indonesia it only reaches 3.1 percent (Republika, 2018) as seen in Table 1.

Table 1. 2017 ASEAN Global Entrepreneurship Index

\begin{tabular}{ccc}
\hline Country & Ranking & GEI \\
\hline Taiwan & 18 & $59 \%$ \\
Singapura & 27 & $53 \%$ \\
Brunei & 53 & $34 \%$ \\
Malaysia & 58 & $33 \%$ \\
Thailand & 71 & $27 \%$ \\
Vietnam & 87 & $23 \%$ \\
Indonesia & $\mathbf{9 4}$ & $\mathbf{2 1 \%}$ \\
Laos & 112 & $18 \%$ \\
Kamboja & 113 & $18 \%$ \\
Myanmar & 127 & $14 \%$ \\
\hline Source: Global Entrepreneurship Index (2017)
\end{tabular}

Indonesia is a country with the largest Muslim population in the world, reaching 203 million people. With the large number of souls, it should be able to describe a large number of muslimpreneur (Antoni, 2014). But the data above is inversely proportional to the number of muslimpreneur in Indonesia. This was explained by Chairil Tanjung that the percentage of muslimpreneur was only $1 \%$ of the total population in Indonesia (MUIDKIJakarta, 2015). The lack of Muslimpreneur in Indonesia is caused by many factors, one of which is allegedly due to family background factors. 
Not a few of the people in Indonesia want their family members to choose to become civil servants or work in a place that is a certain income every month. It is certainly compared to the profession as an entrepreneur who is faced with challenges, creativity, and uncertain income. So for people with certain family backgrounds, work becomes less desirable entrepreneurs.

The impact of that, the government tried to make a breakthrough to increase the number of entrepreneurs in Indonesia. One of them began to work on the pesantren segment. Pesantren play a role as an institution of religious guidance, science, coaching, community development, and at the same time become a cultural node (Ulfa \& Maftukhatusolikhah, 2015). Islamic boarding schools have three main functions, namely: First, as a center for the cadre of religious thinkers (Agent of Excellence). Second, as an institution that prints human resources (Agent of Resource). Third, as an institution that has the power to empower the community (Agent of Development), especially the santri community (Ulfa \& Maftukhatusolikhah, 2015).

Bandung is one of the cities in Indonesia whose economy is quite fast. Many schools try to combine public and religious schools. This can be seen from the many schools that try to combine pesantren-based religious curriculum with the general education curriculum. That way Bandung has had ample opportunities to produce graduates who understand religion but also understand in general education. More specifically the city of Bandung has the potential to print muslimpreneur, this was proven when the Bandung Santripreneur Fest 2019 event was held, many students of the city of Bandung were enthusiastic about following the event. At the event the students were given a briefing about the importance of learning to become an afar entrepreneur after graduating from a pesantren, the students were expected to become reliable entrepreneurs. Based on the explanation from Jimmy Rahmat Hidayat as the event guarantor for the 2019 BSF, alumni santri Gontor will collaborate with the Bandung city HIPMI to provide the Santripreneur debriefing in the Pesantren in the city of Bandung (Republika, 2019).

Entrepreneurship is one of the many aspects of life that has also been discussed in the Qur'an and Hadith. Islam is a kaffah religion which considers that there is no separation between entrepreneurship and religious activities. Islam is a complete and comprehensive religion, Islam is a way of life that strongly encourages human activities in various matters such as entrepreneurship, development, agriculture, industry, science, and commerce. It all shows that Islam is a religion that is not rigid and very accommodating (Juliana, Firmansyah, Cahyaneu, Moslem, \& Fauziyah, 2017). This perspective is certainly different from the perspective of conventional entrepreneurship which still adheres to the capitalist pattern, wherein their paradigm, economic activity (including entrepreneurship) is not related to religious values. This paradigm is often also referred to as secularism, namely the idea of separating religion from life, religion is only placed in the realm of individual nature. (Juliana, Marlin, Saripudin, \& Khatimah, 2017).

Islamic entrepreneurship in Chowdury's view is the process of starting a company to produce goods or provide halal services to make a reasonable profit. In addition, Islamic entrepreneurship does not engage in activities that fail to ensure consumer rights, social responsibility, ethical values and sound business practices (Juliana, 2017)

Islamicpreneur is a new standard term that is currently being talked about in the development of Islamic economics in various countries. Makhrus \& Cahyani (2017) argue that Muslimpreneur means all kinds of activities in establishing, leading, managing, taking risks, and being a business owner in accordance with Islamic teachings. So Muslimpreneur is an effort to encourage the presence of business practices that spread Islamic values in all forms of business activities, it is due to the existence of humans as khalifahs on earth and created by God to always worship Him.

Muslimpreneur is a person who starts and manages a business company following Islamic guidelines. A Muslim businessman will always be careful and avoid the problem of things that are not desirable such as; hoarding, withholding employee salaries, exploitative and cheating on customers. Muslimpreneur behavior is intended to seek blessings while providing the means to live a life that is more beneficial to society (Juliana, 2017).

Whereas Darwis (2017) explains that Muslimpreneur, through an analysis of the relationship of Islamic teachings with entrepreneurship itself, refers more to the words or sentences used in the Qur'an and as-Sunnah that are relevant to entrepreneurship. In this case, there are several words, such as al-amal, al-kasb, al-fi'il, as-sa'u, an-nashru, and ashsa 'n. although each word has different meanings and implications, in general, the sequence of words means working, trying, making a living, and exploring (to work).

In previous studies, not many have expressed the understanding of the intentions of Muslimpreneur specifically, so researchers developed the concept of entrepreneurial intentions in general. Meanwhile, Linan argues that entrepreneurial intentions indicate how much effort a person will make to bring up entrepreneurial behavior (Liñán, 2011). The intention of entrepreneurship is the initial stage of a business development process that is basically long-term (Roujaniah, 2014).

Thus, if the explanation of the entrepreneurial intentions described above is related to the Muslimpreneur definition, that is someone who can deepen the factors of production by adhering to Islamic principles within the scope of Islamic business ethics by being able to produce a product of thought, goods or services for consumption by consumers. by using the principle of halal thoyyiban, both in terms of halal substances and halal substances, in addition, where the goal of an entrepreneur's business is not only to pursue profit alone but also to pursue benefits by avoiding things that are prohibited in Islam (Hidayat, 2017). So it can be concluded that the intention of Muslimpreneur is the degree of how strong a person's desire for entrepreneurship and how much effort is done by that person to realize his desire in entrepreneurship by adhering to Islamic law and business ethics and aiming for success.

The Muslimpreneur intention indicator based on the development of entrepreneurial intentions concept conveyed by (Vemmy, 2013) includes:

1. Desires, namely the desire of someone in starting a business.

2. Preferences, namely choosing to do entrepreneurial activities rather than doing other work

3. Plans are a person's hopes and plan to start entrepreneurial activities in the future.

4. Behavior expectancies, namely a review of the possibility for entrepreneurship with a target to start entrepreneurial activities.

In Islam, a family is also referred to as usrah, nasl, ali, and nasb. The family is the first environment for a child who gets education and guidance from his parents or family members. A child makes the family as a place to lay the foundations of personality at an early age because at a young age the child will be more sensitive to the influence of parental education (Nurudin, 2017).

Carr \& Sequeira (2007) supports the view that family background plays a major role in shaping entrepreneurial intentions. In addition, the researchers also extended family backgrounds to include genetic disposition. These researchers are of the view that the relationship between parents and entrepreneurial experience gives birth to structural patterns and communication that are able to give a strong preference for offspring doing entrepreneurship.

However, Kolvereid in Farrukh (2017) notes that there is an indirect relationship between family background and entrepreneurial intentions. A child who is raised in a family environment that runs entrepreneurship indirectly will get knowledge, 
experience and a real picture of the business world. This is because every individual is able to learn not only from their own experiences but also from others around them. So when they show that the intention to start entrepreneurship is indirectly influenced by previous entrepreneurial exposure. This view is considered that family background has implications for perceptions of business feasibility and desires. The effect on perception afterward is manifested in the high and low of entrepreneurial intentions (Farrukh, Khan, Khan, Ramzani, \& Soladoye, 2017).

The family background indicators described by Slamento in Suyatno \& Muhtarom (2018) are as follows:

1. The way parents educate

2. Relationships between family members

3. The atmosphere of the house

4. The state of the family economy

5. Definition of parents

6. Cultural background

Farrukh (2017) in his research explained that family background was found to have a positive impact on Entrepreneurial Intentions. This is as explained by Drennan, Kennedy, \& Renfrow (2005) who are of the view that initial exposure to entrepreneurship and experience in the family business have an impact on the attitudes and intentions of family members towards entrepreneurship.

This opinion is then supported by the results of research conducted by Meinawati (2018). The results of the study revealed that family background had a positive influence on entrepreneurship intentions. Therefore based on the above explanation, the researchers formulated that family background had an influence on Muslimpreneur Intention.

\section{RESEARCH METHODS}

The method used in this research is the survey method with the explanatory approach. This study uses a hypothesis testing design, the design that is suitable in this study is the design of causality. This research was conducted in the city of Bandung in July-August 2019 with the population of this study were students of MA / SMA pesantren throughout Bandung including MA Al-Inayah Bandung, Assalaam Plus High School Bandung, MA Nurrohmah Bandung, MA Nurul Iman Bandung, and MA Sirnamiskin Bandung.

This type of research is descriptive and verification (empirically testing hypotheses). Descriptive analysis is done to explain the picture of the influence of family background.

This study uses a formative indicator model so that the analytical tool used is Structural Equation Modeling-Partial Last Square (SEM-PLS). PLS is used to find the fundamental relationship between two matrices ( $\mathrm{X}$ and $\mathrm{Y}$ ), which is the latent variable approach to modeling the covariance structure in these two spaces. PLS regression is very suitable when the predictor matrix has more variables than observations, and when there is multicollinearity among X values (Ghazali, 2014).

The reason for using SEM-PLS is that the research objective is to predict the model, not to rely on many assumption tests and because researchers tend to use smaller data. Partial Least Square is not only an analysis whose main function is to design models but can also be used to confirm theories and can be used to explain the presence or absence of relationships between latent variables.

In SEM-PLS analysis the required samples are identical with much smaller data with estimates of 300-100 samples or ten times the scale of the number of formative indicators (Ghazali, 2014). For this reason, this study used a sample of 129 respondents. The technique used is a non-probability-accidental sampling. Then the data collection method used is a questionnaire. The instrument used in this study uses an assessment in the form of a Semantic differential scale with a score range of 1-7 with the following measurement categories as tabulated in Table 2.

Table 2. The scale of Measurement Category

\begin{tabular}{cc}
\hline Skala & Category \\
\hline$X>(\mu+1,0 \sigma)$ & High \\
$(\mu-1,0 \sigma) \leq X \leq(\mu+1,0 \sigma)$ & Moderate \\
$X<(\mu-1,0 \sigma)$ & Low
\end{tabular}

Source: (Azwar, 2006)

\section{RESULTS AND DISCUSSIONS}

Based on the results of the categorization, it is known that the family background variable of each respondent is in the high tendency category with a percentage of $65.89 \%$ or as many as 85 students. In the medium category that is equal to $34.11 \%$ or as many as 44 students. So it can be said that the role of the family background has a considerable impetus towards the intention of a santri to become a muslimpreneur. Partial Least Squares-Structural Equation Modeling (PLS-SEM) Analysis

Based on the results of the categorization, it is known that the family background variable of each respondent is in the high tendency category with a percentage of $65.89 \%$ or as many as 85 students. In the medium category that is equal to $34.11 \%$ or as many as 44 students. So it can be said that the role of the family background has a considerable impetus towards the intention of a santri to become a muslimpreneur. Partial Least Squares-Structural Equation Modeling (PLS-SEM) Analysis.

3.1 Outer Model Testing

Outer model testing is a test to explain the relationship between latent variables and indicators. stages that need to be analyzed in testing the outer model include:

3.1.1. Convergent Validity and AVE

Convergent validity is a tool used to measure reflective validity as a measure of variables that can be seen through the outer loading value of each indicator variable (Juliana, 2017). According to Ghazali (2014) Indicators are said to be valid if the loading factor $>0.70$ as shown in Table 3.

Table3. Loading factor

\begin{tabular}{cccc}
\hline Variable & Loading Factors & CR & AVE \\
\hline Muslimpreneur intention (Y) & & 0.868 & 0.621 \\
\hline IMP1 & 0.830 & & \\
IMP2 & 0.753 & & \\
IMP3 & 0.802 & & \\
\hline
\end{tabular}




\begin{tabular}{cccc}
\hline IMP4 & 0.766 & & \\
\hline Family background $(\mathrm{X})$ & & 0.873 & 0.580 \\
\hline LK1 & 0.737 & & \\
LK2 & 0.778 & & \\
LK3 & 0.724 & & \\
LK4 & 0.751 & & \\
LK5 & 0.814 & & \\
\hline
\end{tabular}

Source: results of data processing

Based on the above output, it can be said that the research indicators do not have a convergent validity problem. So that this test is worth proceeding to the next stage.

\subsubsection{Discriminant Validity}

The discriminant validity test is performed through the Fornell-Lacker Criterion analysis, which is a validity test that is performed by comparing correlations between variables or constructs with the square root of Average Variance Extracted $(\sqrt{ })$. Prediction is said to have a good AVE value if the value of the square root AVE of each latent variable is greater than the correlation between other latent variables. Following is the Fornell-Lacker Criterion Table 4 and 5.

Table 4. Fornell-Lacker Criterion

\begin{tabular}{ccc}
\hline & IMP & LBK \\
\hline IMP & 0.788 & \\
LBK & 0.702 & 0.761 \\
\hline & Table 5. Discriminant Validity HTMT \\
\hline & Muslimpreneur & Family \\
& intention & background \\
\hline IMP & 0.865 & \\
LBK & & \\
\hline
\end{tabular}

\subsection{Inner Model Testing}

Inner model testing is done through R-Square (R2), Multicollinearity, F-Square (F2), Q-Square (Q2) and Good of Fit (GoF) analysis. Following:

3.2.1. R-Square Analysis (R2)

R-Square (R2) analysis aims to explain the large proportion of the variation of the dependent variable that can be explained by all independent variables. According to Chin, the R2 result of 0.67 indicates that the model is good, 0.33 is moderate while 0.19 is weak (Ghozali, 2014).

Based on testing the coefficient of determination, it can be seen that R2 of the Muslimpreneur intention variable is 0.493. this means that the independent variable, namely family background, is able to explain the dependent variable, namely Muslimpreneurr intention of $49.3 \%$ while the remaining $50.7 \%$ is explained or influenced by other variables outside the model in this study. The R2 result of 0.493 according to Chin indicates that the variables in the model have a moderate relationship.

\subsubsection{Multicollinearity}

Multicollinearity analysis aims to determine that a construct that is measured is completely different from other constructs as seen in Table 6. If the tolerance value $<0.20$, then multicollinearity is detected or if the VIP value $>5$ then multicollinearity can be suspected (Garson, 2016).

Table 6. VIF

\begin{tabular}{ccc}
\hline & IMP & LBK \\
\hline IMP & & \\
LBK & 1.000 & \\
\hline
\end{tabular}

Based on the above output it is concluded that this study is free from multicollinearity problems.

3.3.3. F-Square $\left(F^{2}\right)$

This test is carried out to analyze the level of influence of latent variable predictors whether weak, medium or large at the structural level. F2 values of $0.02,0.15$ and 0.35 indicate the predictor of latent variables having a weak, moderate, and large influence on the structural level as depicted in Table 7.

Table 7. F-Square

\begin{tabular}{lcl}
\hline \multicolumn{3}{c}{ TMP } \\
\hline IMPr & LBK \\
LBK & 0,973 \\
\hline
\end{tabular}

Based on the F-Square output above, it can be seen that the influence of family background variables on the intention variable of Muslimpreneur has a large degree of influence because it exceeds the value of 0.35 which is 0.973 .

3.3.4. Q-Square $\left(Q^{2}\right)$

This test is carried out to analyze how well the observational values generated by the model. Q-Square values that exceed zero (0) have a good predictive relevance value, whereas if a Q-Square value less than zero indicates that the model lacks good predictive relevance.

$$
\begin{gathered}
\mathrm{Q}^{2}=1-\left(1-\mathrm{R}^{2}\right) \\
\mathrm{Q}^{2}=1-(1-0.493) \\
\mathrm{Q}^{2}=0.243
\end{gathered}
$$

Based on the results of these calculations, the research model can be said to have a good predictive relevance value because it has a value of more than zero $(0)$. 


\section{Good of Fit (GoF)}

This analysis serves to evaluate the structural model and overall measurement. The GoF value category is 0.1 categorized as small, 0.25 categorized as medium and 0.38 categorized as large. Following is the formula used to calculate the Goodness of Fit value:

$$
\mathrm{GoF}=\sqrt{\left((\mathrm{AVE})^{-} \times\left(\mathrm{R}^{\wedge} 2\right)^{-}\right)}
$$

Based on the results of calculations that have been made, the GoF result is 0.544 which is greater than 0.38 . Thus it can be concluded that the model built has a good Goodness of Fit. Then the research model is stated robust as seen in Figure 1.

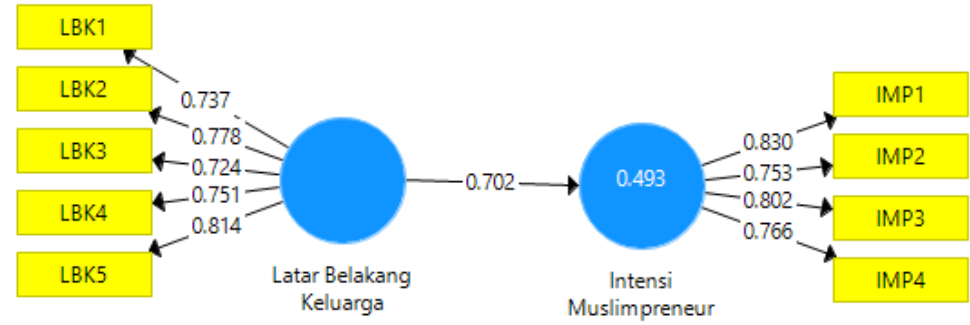

\section{HYPOTHESIS TEST}

Figure 1. Outer SEM-PLS Research Model

Testing research hypotheses are analyzed through a comparison of t-statistic and t-table values or probability values. To test the hypothesis of this study using a significance level of 5\%. If using the t-statistic test, the t-table at the $5 \%$ significance level is 1.96 because the sample exceeds 30 . So the hypothesis testing criteria HA is accepted and $\mathrm{H} 0$ is rejected when t-statistics $>1.96$ or 2.326 . Meanwhile, HA testing criteria are accepted using probability testing when the P-Values value $<0.01$ or 0.05 . Here is a model for analyzing the significance of variables obtained through bootstrapping calculations as seen in Figure 2.

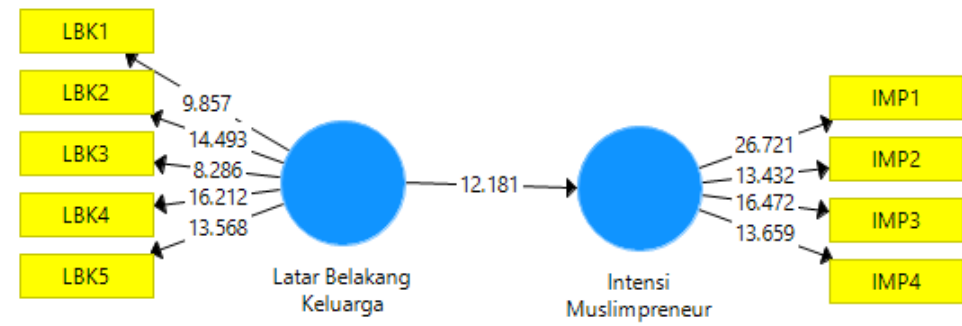

Figure 2. Bootstrapping Testing Output

To see the acceptance or rejection of the hypothesis can be seen from the following bootstraping report as tabulated in Table 8.

Table 8. Path coefficient

\begin{tabular}{llcccc}
\hline & (0) & (M) & (STDEV) & T Statistics & P Values \\
\hline LBK-> IMP & 0.702 & 0.716 & 0.058 & 12.181 & 0 \\
\hline
\end{tabular}

Family background variables have a positive and significant effect on muslimpreneur intentions. This is evidenced by the $t-$ statistic value of 12,181 where the value is greater than 1.96 and the significance at alpha is $0.5 \%$ (P-values $<0.005$ ). Thus the hypothesis formulation is accepting HA:

HA: $\beta>0$, meaning that there is an influence between family background on the intention of the muslimpreneur.

The results of tests that have been carried out prove that there is an influence of family background with the intention of an Islamic Senior High School / Islamic boarding school student in Bandung to become a Muslimpreneur. This test states that the higher the support from family background, the higher the intention of a santri to become a muslimpreneur. Where these findings support the theory that states that family background has a significant influence on a person.

Previous research considers that family background has implications for perceptions of business feasibility and desires. The effect on perception afterward is manifested in the high and low of entrepreneurial intentions (Farrukh, Khan, Khan, Ramzani, \& Soladoye, 2017). This is in line with previous research conducted by Meinawati (2018) where the family has a very important role in shaping one's behavior, including in entrepreneurial behavior. One of the intentions of entrepreneurship is growing due to the influence of family background which can be a role model in starting to run entrepreneurship. The findings made (Farrukh, Khan, Khan, Ramzani, \& Soladoye, 2017) and Meinawati (2018) state that there is a positive and significant influence of family environment on entrepreneurial interest.

Thus it can be concluded that the findings in this study which state that family background has a positive and significant effect on the intention of the muslimpreneur are in accordance with the theory and also previous studies. Therefore, based on the findings in this study the right steps to increase the intentions of Muslimpreneur in Indonesia is to improve family understanding of Islamic entrepreneurship so that the processes that occur in the family environment include: how to educate parents, relations between families, home atmosphere, economic conditions, understanding parents are able to support, direct and encourage children to become a muslimpreneur.

\section{CONCLUSION}

Based on the results of research and discussion, the conclusions of this study can be explained that Muslimpreneur among students in MA / SMA pesantren in the city of Bandung showed very good development, this is evidenced by the santripreneur program 
initiated by the West Java provincial government where each pesantren is required to provide lessons and understanding of students in Islamic entrepreneurship.

Family background in students of MA / SMA boarding schools in Bandung in the high category. This means that individuals who have a family background have a process of how to educate parents, relationships between families, home atmosphere, economic conditions and understanding of parents who are very supportive of the individual's intention to become a muslimpreneur.

This study provides recommendations for Santri MA / SMA Pesantren able to implement the knowledge gained in pesantren, especially Islamic business and entrepreneurship that is taught in pesantren. This is because the intention of the Muslimpreneur in santri is a source for the birth of Islamic entrepreneurs in the future. So that if the intentions and potential of students are able to be organized, the entrepreneurial ratio in Indonesia will increase, the problem of unemployment will decrease because the enthusiasm and determination of students after graduating from pesantren are no longer as job seekers but as opening new jobs.

\section{References}

Antoni. (2014). Muslim Entrepreneurship: Membangun Muslim Peneurs Characteristics Dengan Pendekatan Knowladge Based Economy. EL-HIKAM: Jurnal Pendidikan dan Kajian Keislaman, 326-354.

Carr, J. C., \& Sequeira, J. M. (2007). Prior family business exposure as intergenerational influence and entrepreneurial intent: A Theory of Planned Behavior approach. Journal of Business Research, 1090-1098.

Chaudhary, R. (2017). Demographic factors, personality and entrepreneurial inclination. Education + Training, $171-187$.

Darwis, M. (2017). Entrepreneurship Dalam Perspektif Islam: Meneguhkan Paradigma Pertautan Agama dan Ekonomi. Iqtishoduna, 190-222.

Drennan, J., Kennedy, J., \& Renfrow, P. (2005). Impact of Childhood Experiences on the Development of Entrepreneurial Intentions. International Journal of Entrepreneurship and Innovation, 1-14.

Farrukh, M., Khan, A. A., Khan, M. S., Ramzani, S. R., \& Soladoye, B. S. (2017). Entrepreneurial intentions: the role of familial factors, personality traits and self-efficacy. World Journal of Entrepreneurship, Management and Sustainable Development, 1-28.

Garson, G. D. (2016). Partial Least Squares: Regression \& Structural Equation Models. Asheboro, NC: Statistical Associates Publishing.

Ghazali, I. (2014). Struktural Equation Modeling: Metode dengan Partial Lest Square. Semarang: Badan Penerbit Universitas Dipenogoro.

Hidayat, N. M. (2017). Faktor-faktor yang Mempengaruhi Motivasi Mahasiswa Menjadi Entrepreneur Syariah. Jurnal Syarikah, 403418.

Hmieleski, K. M., \& Baron, R. A. (2008). When does entrepreneurial self-efficacy enhance versus reduce firm performance? Strategic Entrepreneurship Journal, 57-72.

Juliana. (2017). Syariahpreneur Dalam Mewujudkan Kesejahteraan Masyarakat. Bandung: Corleone Books.

Juliana, Faathir, M., \& Shultan, M. (2019). Implementasi Etika Bisnis Islam Pelaku Usaha Mikro : Studi Kasus Pada Pelaku Usaha Mikro Syariah Puspa Bank Indonesia Wilayah Jawa Barat Di Bandung Tahun 2017. Strategic, 36-43.

Juliana, Firmansyah, Cahyaneu, A., Moslem, H., \& Fauziyah, I. (2017). Shari'a Compliance to Improve the Competitiveness of the Industry of Hijab. ICIEBP - 1st International Conference on Islamic Economics, Business and Philanthropy, 693-697.

Juliana, Marlin, R., Saripudin, U., \& Khatimah, H. (2017). Syariapreneur: The New Paradigm of Islamic-Based Entrepreneurship. Proceedings of the 1st International Conference on Islamic Economics, Business, and Philanthropy, 668-672.

Kompas. (2018, September 17). Lulusan SMK jadi Pengusaha? Bisa! Retrieved from Kompas: https://edukasi.kompas.com

Liñán, F. (2011). Factors affecting entrepreneurial intention levels: a role for education. Intrepreneural Management Journal, 195218.

Makhrus, \& Cahyani, D. P. (2017). Konsep Islamicpreneurship Dalam Upaya Mendorong Praktik Bisnis Islami. Islamidina, 1-20.

Media Indonesia. (2018, Juli 25). Kemenpora Mendorong Santri Jadi Wirausahawan. Retrieved from Media Indonesia: http://mediaindonesia.com

Media Indonesia. (2018, Oktober 19). Pendidikan Kurang Mendorong Minat Kewirausahaan. Retrieved from Media Indonesia: http://mediaindonesia.com

Media Indonesia. (2018, June 5). Rasio Wirausaha Indonesia Sentuh 7\%. Retrieved from Media Indonesia: https://mediaindonesia.com

Meinawati, N. (2018). Pengaruh Latar Belakang Keluarga dan Pendidikan Kewirausahaan terhadap Intensi Berwirausaha melalui Efikasi Diri. Indonesian Journal of Economics Education, 55-64.

MUIDKIJakarta. (2015, Juni 30). Persentase Pebisnis Muslim Cuma 1\%. Retrieved from MUI DKI Jakarta: https://www.muidkijakarta.or.id

Republika. (2018, Oktober 18). Enggartiasto: Tingkat Kewirausahaan di Indonesia Rendah. Retrieved from Republika.co.id: https://www.republika.co.id

Republika. (2018, Januari 23). Santri Diharapkan Jadi Pengusaha. Retrieved from Khazanah Republika: https://khazanah.republika.co.id

Republika. (2019, April 24). Bandung Santripreneur Fest Targetkan Lima Ribu Pengunjung. Retrieved from Khazanah: https://khazanah.republika.co.id

Roujaniah. (2014). Pengaruh Faktor-faktor Demografi dan Karakteristik Pribadi terhadap keinginan Berwirausaha Mahasiswa unggul Universitas Esa Unggul. Forum Ilmiah, 137-148.

Suyatno, A., \& Muhtarom. (2018). Pengaruh Lingkungan Keluarga Dan Pembelajaraan Kewirausahaan Terhadap Intensi Technopreneurship Mahasiswa Manajemen Ilmu Komputer. Prosiding SENDI_U, 171-179.

Ulfa, N., \& Maftukhatusolikhah. (2015). Minat Wirausaha Kaum Santri dan Faktor-Faktor Yang Mempengaruhinya (Studi Pada Pondok Pesantren Ar -Riyadh Palembang. I-Economics Journal, 52-65.

Vemmy, S. C. (2013). Faktor-faktor yang mempenga ruhi intensi berwirausaha siswa smk di Yogyakarta. Jurnal Pendidikan Vokasi, 117-125. 